\title{
Energy-Efficient Renovation Principles for Prefabricated Timber-Frame Residential Buildings
}

\section{Energetski učinkovita načela obnove montažnih stambenih zgrada s drvenim okvirom}

\author{
Original scientific paper • Izvorni znanstveni rad \\ Received-prispjelo: 30. 8. 2011. \\ Accepted-prihvaćeno: 6. 9. 2012. \\ UDK: $630 * 833.21$ \\ doi:10.5552/drind.2012.1127
}

\begin{abstract}
The timber construction along with the use of suitable and correctly oriented glazing surfaces, whose thermal and strength properties have been considerably improved over the years, represents a great potential in residential and public building construction. However, necessary renovations of the older structures, which present quite a large share of residential fund, should not be overlooked. Moreover, those structures should be adequately energy renovated by the year 2020. Therefore, the key contribution of this paper is the presentation of the available renovation principles, and namely a combination of the improvement of buildings envelope thermal properties, usage of a proper type of installation and share of glazing surfaces in the south-oriented façade, according to affordable investment input. In order to achieve minimal heating and cooling annual energy demand, in the current parametric study, different options were carried out with double-layer and triple-pane glazing, installed in three different types of wall elements, demonstrating the value of optimal glazing surface.
\end{abstract}

Keywords: timber building, glazing, energy efficiency, renovation

SAŽETAK・Drvena konstrukcija, uz uporabu odgovarajućih i pravilno orijentiranih staklenih površina čija su toplinska svojstva i čvrstoća tijekom godina znatno poboljšani, velik su potencijal u gradnji stambenih i javnih zgrada. Pritom ne smije biti zanemarena ni obnova starijih objekata, koji čine prilično velik udio u stambenom fondu. Usto ti bi objekti do 2020. godine trebali biti odgovarajuće energetski obnovljeni. Dakle, važan doprinos ovog članka jest predstavljanje raspoloživih načela obnove kao što su kombinacija poboljšanih toplinskih svojstava fasade zgrade, primjena odgovarajućeg tipa instalacija i udjela staklenih površina na južnoj fasadi, ovisno o mogućemu investicijskom ulaganju. Kako bi se postigla minimalna godišnju potreba za grijanjem i hlađenjem, $u$ parametarskoj studiji izvedene su različite mogućnosti s dvoslojnim i troslojnim zastakljenjem, ugrađenima u tri različita tipa zidnih elemenata, čime se demonstrira vrijednost optimalnih staklenih površina.

Ključne riječi: drvena gradnja, zastakljivanje, energetska učinkovitost, obnova

\footnotetext{
${ }^{1}$ The authors are assistant professor and full professor at the Faculty of Civil Engineering, University of Maribor, Slovenia. ${ }^{2}$ The author is assistant professor at the Department of Wood Science and Technology, Biotechnical Faculty, University of Ljubljana, Slovenia.

Autori su docentica i redoviti profesor Građevinskog fakulteta Sveučilišta u Mariboru, Slovenija. ${ }^{2}$ Autorica je docentica Biotehničkog fakulteta Sveučilišta u Ljubljani, Slovenija.
} 


\section{INTRODUCTION}

\section{UVOD}

Timber as a material for load bearing construction represents a future challenge for residential and public buildings. Being a natural raw material, timber represents one of the best choices for energy efficient construction since it is also a material with good thermal properties, compared to other construction materials. In addition, it plays an important role in the reduction of the $\mathrm{CO}_{2}$ emissions (Natterer, 2009), it has good mechanical properties (Vratuša et al., 2011) and ensures a comfortable indoor living climate. Timber construction has better thermal properties than conventional brick or concrete construction methods, even with smaller wall thickness. Considering the growing importance of energy-efficient building methods, timber construction will play an increasingly important role in the future.

Residential buildings represent the biggest share (47\%) of the existing buildings is Slovenia. More than half of them are made of brick (56\%), $16 \%$ of concrete and mixed construction, and the rest made of materials including timber are represented to a smaller extent (Kitek Kuzman et al., 2010). Focusing to the Slovenian timber construction, current rise has been noticed, even though the percentage of new timber buildings in Slovenia is still small regarding the entire new construction, especially in the public buildings sector. In 2010 (SORS), the percentage of newly built pre-fabricated houses, mostly one or two-family, exceeded $15 \%$ and the percentage is expected to increase to $20-30 \%$ over the next five years.

The dominating methods of timber construction in Slovenia include a timber-frame construction, balloon and massive construction. Currently, most Slovenian companies offer houses with timber-frame con- struction. Timber panel construction has had its own production in Slovenia and Croatia for more than 35 years. The beginnings of pre-fabricated construction started after the second world war, when the barracks were put up for the people who had been left without shelter and those who had migrated from the countryside. Over the past thirty years, timber in Europe construction has undergone major changes. The most important changes introduced are the following (Premrov, 2008): transition from on-site construction to factory prefabrication, transition from elementary measures to modular building and development from a single-panel to a macro-panel wall prefabricated panel system. All of these greatly improve the speed of building.

In timber-frame buildings, the basic vertical load bearing elements are panel walls consisting of load bearing timber frames and sheathing boards. Depending on wall dimensions, one can distinguish between singlepanel and macro-panel wall systems. The single-panel was based on the individual smaller elements in dimensions of $1.30 \mathrm{~m}(1.25 \mathrm{~m}) \times 2.5 \mathrm{~m}$ to $2.65 \mathrm{~m}$ (Figure $1 \mathrm{a})$. The height of the wall elements met the height of the floor and the length of the ceiling elements the span of the bridged field. The macro-panel system has been developed from the single-panel system in the last two decades and represents an important milestone in panel timber frame building. The aim of the system is to provide whole wall assemblies, including windows and doors, which are totally constructed in a horizontal plane in a factory from where they are transported to the building-site. Prefabricated timber-frame walls, as the main vertical bearing capacity elements, of typical dimensions with a width of $1250 \mathrm{~mm}$ and a height of 2500-2600 $\mathrm{mm}$, are composed of a timber frame and sheets of board-material fixed by mechanical fasteners, usually staples, to one or both sides of the timber frame (Figure 1c).

Table 1 Composition of analysed macro-panel (TF 3) and single-panel (TFCL 2, 3) timber-frame wall elements

Tablica 1. Kompozicija analiziranih makropanelnih (TF 3) i jednopanelnih (TFCL 2, 3) zidnih elemenata s drvenim okvirom

\begin{tabular}{|c|c|c|c|c|c|}
\hline \multicolumn{2}{|l|}{ TF 3} & \multicolumn{2}{|l|}{ TFCL 2} & \multicolumn{2}{|l|}{ TFCL 3 - renovation } \\
\hline material / materijal & $d, \mathrm{~mm}$ & material / materijal & $d, \mathrm{~mm}$ & material / materijal & $d, \mathrm{~mm}$ \\
\hline $\begin{array}{l}\text { rough coating } \\
\text { hrapava obloga }\end{array}$ & 10 & $\begin{array}{l}\text { wooden planks } \\
\text { drvene oplate }\end{array}$ & 22 & $\begin{array}{l}\text { rough coating } \\
\text { hrapava obloga }\end{array}$ & 10 \\
\hline $\begin{array}{l}\text { wood fibreboard } \\
\text { ploče vlaknatice }\end{array}$ & 60 & / & I & $\begin{array}{l}\text { mineral wool } \\
\text { mineralna vuna }\end{array}$ & 40 \\
\hline 1 & 1 & $\mathrm{TSS}^{* * *} /$ open air gaps / bitumen & 0.5 & $\begin{array}{l}\text { gypsum fibreboard } \\
\text { gipsane vlaknatice }\end{array}$ & 15 \\
\hline \multirow{3}{*}{$\begin{array}{l}\text { cellulose fibre / } \mathrm{TF}^{*} \\
\text { celulozna vlakna }\end{array}$} & \multirow[t]{3}{*}{360} & $\mathrm{TSS}^{* * *} /$ open air gaps $/ \mathrm{TF}^{*}$ & 20 & \multirow{3}{*}{$\begin{array}{l}\text { mineral wool / } \mathrm{TF}^{*} \\
\text { mineralna vuna }\end{array}$} & \multirow[t]{3}{*}{100} \\
\hline & & $\begin{array}{l}\text { bitumen sheet cardboard / } \mathrm{TF}^{*} \\
\text { TF*MW }\end{array}$ & 0.5 & & \\
\hline & & $\begin{array}{l}\text { mineral wool / } \mathrm{TF}^{*} \\
\text { mineralna vuna }\end{array}$ & 80 & & \\
\hline $\mathrm{OSB}^{* *}$ & 15 & $\begin{array}{l}\text { aluminium foil } \\
\text { aluminijska folija }\end{array}$ & & $\begin{array}{l}\text { aluminium foil } \\
\text { aluminijska folija }\end{array}$ & \\
\hline \multirow[t]{2}{*}{$\begin{array}{l}\text { gypsum plasterboard } \\
\text { gipsana fasadna ploča }\end{array}$} & \multirow[t]{2}{*}{12.5} & $\begin{array}{l}\text { particleboard } \\
\text { ploča iverica }\end{array}$ & 13 & $\begin{array}{l}\text { particleboard } \\
\text { ploča iverica }\end{array}$ & 13 \\
\hline & & $\begin{array}{l}\text { gypsum plasterboard } \\
\text { gipsana fasadna ploča }\end{array}$ & 10 & $\begin{array}{l}\text { gypsum plasterboard } \\
\text { gipsana fasadna ploča }\end{array}$ & 10 \\
\hline $\begin{array}{l}\text { total thickness, } \mathrm{mm} \\
\text { ukupna debljina, } \mathrm{mm}\end{array}$ & 457.5 & $\begin{array}{l}\text { total thickness, } \mathrm{mm} \\
\text { ukupna debljina, } \mathrm{mm}\end{array}$ & 146 & $\begin{array}{l}\text { total thickness, } \mathrm{mm} \\
\text { ukupna debljina, } \mathrm{mm}\end{array}$ & 188 \\
\hline$U_{\text {wall }}-$ value, $\mathrm{W} / \mathrm{m}^{2} \mathrm{~K}$ & 0.102 & $U_{\text {wall }}$-value, $\mathrm{W} / \mathrm{m}^{2} \mathrm{~K}$ & 0.48 & $U_{\text {wall }}$-value, $\mathrm{W} / \mathrm{m}^{2} \mathrm{~K}$ & 0.30 \\
\hline
\end{tabular}

*timber frame / *drveni okvir, $* *$ oriented strand board / **ploča s orijentiranim iverjem, ${ }^{* * *}$ timber sub-structure / *** drvene podstrukture 

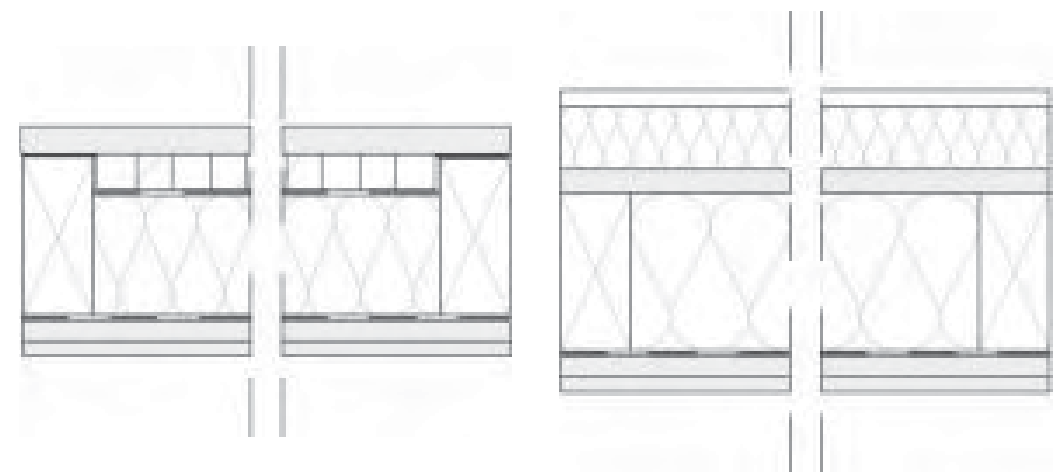

a)

Figure 1 a) single-panel system (TFCL2); b) renovated single-panel system (TFCL 3), c) timber-frame wall element with I-studs (TF 3)

Slika 1. a) jednopanelni sustav (TFCL2); b) obnovljeni jednopanelni sustav (TFCL 3), c) zidni element s drvenim okvirom i I-stupovima (TF 3)

Between the timber studs and girders, a thermal insulation material is inserted whose thickness depends on the type of external wall. Composition of all analysed wall elements is presented in detail in Table 1.

The first single-panel systems in Slovenia were used by Marles and Jelovica. In Slovenia and Croatia there are a few settlements built in the early 70 s. For an illustration, Table 2 gives figures of the houses produced by the Company Marles Houses in the period from 1964 to 1987.

Those first pre-fabricated houses had very good thermal properties of external envelope. Thermal transmittance of the best panel types was always much lower than provided by regulations; for example thermal insulation improved by nearly three times from 1963 to 1972, and after 1992 it was almost four times better than specified by the current national regulations (Figure 2). Due to the reduction of energy losses in the newly

Table 2 Number of Marles' pre-fabricated houses from 1964 to 1987 (archive company Marles hiše Maribor).

Tablica 2. Broj Marlesovih montažnih kuća od 1964. do 1987. (arhiva tvrtke Marles hiše, Maribor)

\begin{tabular}{|l|c|}
\hline $\begin{array}{l}\text { MARLES pre-fabricated } \\
\text { houses (purpose) / MARLES } \\
\text { montažne kuće (namjena) }\end{array}$ & $\begin{array}{c}\text { Produced number } \\
\text { Broj proizvedenih kuća }\end{array}$ \\
\hline $\begin{array}{l}\text { residential settlements, terraced } \\
\text { houses / stambena naselja, } \\
\text { terasaste kuće }\end{array}$ & 590 \\
\hline schools / škole & 90 \\
\hline kindergartens / dječji vrtići & 360 \\
\hline health centres / domovi zdravlja & 40 \\
\hline $\begin{array}{l}\text { individual structures } \\
\text { individualni objekti (1964-1999) }\end{array}$ & 10000 \\
\hline
\end{tabular}

built residential structures, the first measure introduced by producers was a gradual reduction of thermal transmittance of external wall elements, resulting in the increase of thickness of the timber-frame wall elements, thus enabling the installation of thicker thermal insulation. Detailed composition of construction of the older single-panel external wall elements, as well as the newer macro-panel system, are explicitly presented in Table 1, with the additional graphic presentation in Figure 1. Figure 2 only shows data until the year 1992, when

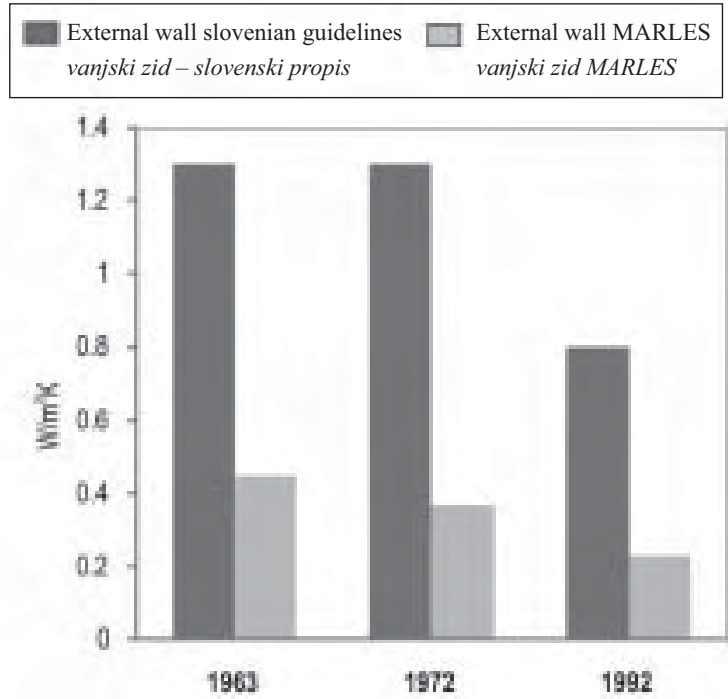

Figure 2 Thermal transmittance of external wall elements - $U$-value comparison of the Marles' wall with the Slovene regulations in the period 1963 to 1992

Slika 2. Toplinski prijenos vanjskih zidnih elemenatausporedba $U$-vrijednosti Marlesova zida sa slovenskim propisima u razdoblju od 1963. do 1992. 
the external wall elements met, for the first time, the requirements of the regulations currently applicable in Slovenia regarding energy efficient construction, so that the thermal transmittance of exterior was, for the first time, lower than the prescribed limit value of $0.28 \mathrm{~W} /$ $\mathrm{m}^{2} \mathrm{~K}$, i.e. it has nearly reached the value for light constructions, which is $0.20 \mathrm{~W} / \mathrm{m}^{2} \mathrm{~K}$ (PURES, 2010). Therefore, all prefabricated timber framed structures set up before the year 1992 are considered as a fund needing energy efficient renovation by the year 2020. The latter refers to the wide-ranging package on climate change adopted by the European Union, the overall 20-20-20 targets, which are binding for buildings, too. Therefore, the energy performance of the existing buildings has to be improved through a complex process of energy efficient renovation, and likewise a sustainable new construction of energy-efficient buildings with the use of renewables has to be performed.

\section{ENERGY-EFFICIENT BUILDINGS}

\section{ENERGETSKI UČINKOVITE ZGRADE}

Researching energy efficiency of buildings is not a matter of the last decade only, since the first intensive studies related to energy and buildings were already carried out in the seventies and eighties of the last century. Many studies focusing on the research of specific parameters influencing energy performance of buildings, such as Johnson et al. (1984) and Steadman et al. (1987) have been performed since then. Previous research findings indicate that the process of defining the optimal model of a building is very complex. The most important parameters influencing energy-performance of buildings are listed below:
- location of the building and climate data for the specific location,

- orientation of the building,

- properties of installed materials, such as timber, glass, insulation, boards, etc.,

- building design (shape factor, length-to-width ratio, window-to-wall area ratio, building envelope properties, windows properties),

- selection of active technical systems.

According to the Slovene legislative framework, particularly the Energy Act, the system of energy performance certification is defined in Rules on the methodology of construction and issuance of building energy certificates (2009). On the basis of these rules, the classification of energy-efficient houses was carried out, as listed in Table 3.

Table 3 clearly shows that energy efficient structures can be constructed only by an adequate combination of external envelope efficient insulation and high quality glazing installation. Respecting climate change conditions and the subsequent European directions related to energy performance of buildings, the building industry must construct a nearly zero energy house by 2020. Searching for the optimal model of an energyefficient house has, therefore, become an issue of major importance. Similar concept of optimal solution will consequently have to be introduced into the field of renovation of numerous older buildings, which are far from achieving standards of energy efficient buildings. Therefore, our analysis is directed into the field of prefabricated timber-frame construction, which will try to find an optimal renovation solution as combination of additional layers of insulation on the external wall elements and double-layer or triple-pane quality glazing.

Table 3 Classification of energy-efficient houses on the basis of "Rules on the methodology of construction and issuance of building energy certificates"

Tablica 3. Klasifikacija energetski učinkovitih kuća na temelju Pravilnika o metodologiji gradnje i izdavanja energetskih certifikata za zgrade.

\begin{tabular}{|c|c|c|c|}
\hline $\begin{array}{l}\text { Degree / Classification in } \\
\text { accordance with the rules } \\
\text { Klasifikacija u skladus } \\
\text { pravilima }\end{array}$ & $\begin{array}{l}\text { Generally used classifica- } \\
\text { tion in practice } \\
\text { Općenito primjenjivana } \\
\text { klasifikacija u praksi }\end{array}$ & $\mathbf{Q}_{\mathrm{h}}{ }^{*}\left(\mathrm{kWh} / \mathrm{m}^{2} \mathrm{a}\right)$ & $\begin{array}{l}\text { Variation of execution / Varijanta izvedbe } \\
\text { (according to Praznik and Kovič, 2010) }\end{array}$ \\
\hline Class C / klasa C & $\begin{array}{l}\text { minimal requirements for } \\
\text { low-energy house } \\
\text { minimalni zahtjevi za } \\
\text { nisko-energetsku kuću }\end{array}$ & $35-50(60)$ & $\begin{array}{l}\text { classical prefabricated construction, conventional } \\
\text { heating system, contemporary windows (doors), } \\
\text { no central ventilation system / klasična konstru- } \\
\text { kcija, konvencionalni sustav grijanja, suvremeni } \\
\text { prozori, bez središnjega ventilacijskog sustava }\end{array}$ \\
\hline Class B2 / klasa B2 & $\begin{array}{l}\text { low-energy house } \\
\text { niskoenergetska kuća }\end{array}$ & $25-35$ & $\begin{array}{l}\text { thermally improved building envelope } \\
\text { toplinski poboljšana fasada zgrade }\end{array}$ \\
\hline Class B1 / klasa B1 & $\begin{array}{l}\text { better low-energy house } \\
\text { bolja niskoenergetska kuća }\end{array}$ & $15-25$ & $\begin{array}{l}\text { thermally improved building envelope }+\mathrm{HRV}^{* *} \\
+\mathrm{HP}^{* * *} / \text { toplinski poboljšana fasada zgrade }+ \\
H R V^{* *}+H P^{* * *}\end{array}$ \\
\hline Class A2 / klasa A2 & $\begin{array}{l}\text { passive house } \\
\text { pasivna kuća }\end{array}$ & $10-15$ & $\begin{array}{l}\text { additionally thermally improved building } \\
\text { envelope }+\mathrm{HRV}+\mathrm{HP} / \text { dodatno toplinski } \\
\text { poboljšana fasada zgrade }+H R V+H P\end{array}$ \\
\hline Class A1 / klasa A1 & 1-litre house & $\leq 10$ & $\begin{array}{l}\text { additionally thermally improved building } \\
\text { envelope }+\mathrm{HRV}+\mathrm{HP}+\text { improved U-value of } \\
\text { windows (doors) / dodatno toplinski poboljšana } \\
\text { fasada zgrade }+H R V+H P+\text { poboljšana } \\
U \text {-vrijednost prozora (vrata) }\end{array}$ \\
\hline
\end{tabular}

* specific annual heating demand / specifična godišnja potreba, **heat recovery ventilation / povrat energije, ***heat pump / toplinska pumpa 


\section{NUMERICAL STUDY}

\section{NUMERIČKA STUDIJA}

This chapter presents a numerical case study of a two-storey house and its parametric analysis of the impact of the glazing-to-wall area ratio on energy demand. The influence of south oriented glazing area size on heating and cooling energy demand is analysed in the case-study of a single-family house, carried out with three different types of external wall elements:

a) a new macro-panel timber-frame wall element (TF 3 ), which satisfies the requirements of a passive house design, of a total thickness of $456.5 \mathrm{~mm}$ and $U_{\text {wall }}$ value of $U=0.102 \mathrm{~W} / \mathrm{m}^{2} \mathrm{~K}$ (Table 1, Figure 1c),

b) an old classical single-panel timber-frame wall element (TFCL 2) of a total thickness of $146 \mathrm{~mm}$ and $U_{\text {wall }}$ value of $U=0.480 \mathrm{~W} / \mathrm{m}^{2} \mathrm{~K}$ (Table 1 , Figure 1a).

c) a renewed timber-frame single-panel wall element (TFCL 3) of a total thickness of $195 \mathrm{~mm}$ and a $U_{\text {wall }}$ value of $0.30 \mathrm{~W} / \mathrm{m}^{2} \mathrm{~K}$, which is developed from the TFCL 2 old system by inserting an additional insulation in the external side of timber frame (Table 1, Figure 1b) - case of renovation.

\subsection{Simulation model}

3.1. Simulacijski model

\section{Description of the base case study model}

The external horizontal dimensions are $11.66 \mathrm{~m} \mathrm{x}$ $8.54 \mathrm{~m}$ for the ground floor and $11.66 \mathrm{~m} \mathrm{x} 9.79 \mathrm{~m}$ for the upper floor (Figure 3 ). The total heated floor area is $168.40 \mathrm{~m}^{2}$ and the total heated volume is $437.80 \mathrm{~m}^{3}$.

\section{Climate and orientation}

The house is located in Ljubljana with its longer side, the large glazed area, facing south. The city of Ljubljana is located at an altitude of 298 metres, latitude of $46^{\circ} 03^{\prime}$ and longitude of $14^{\circ} 31^{\prime}$ east. According to

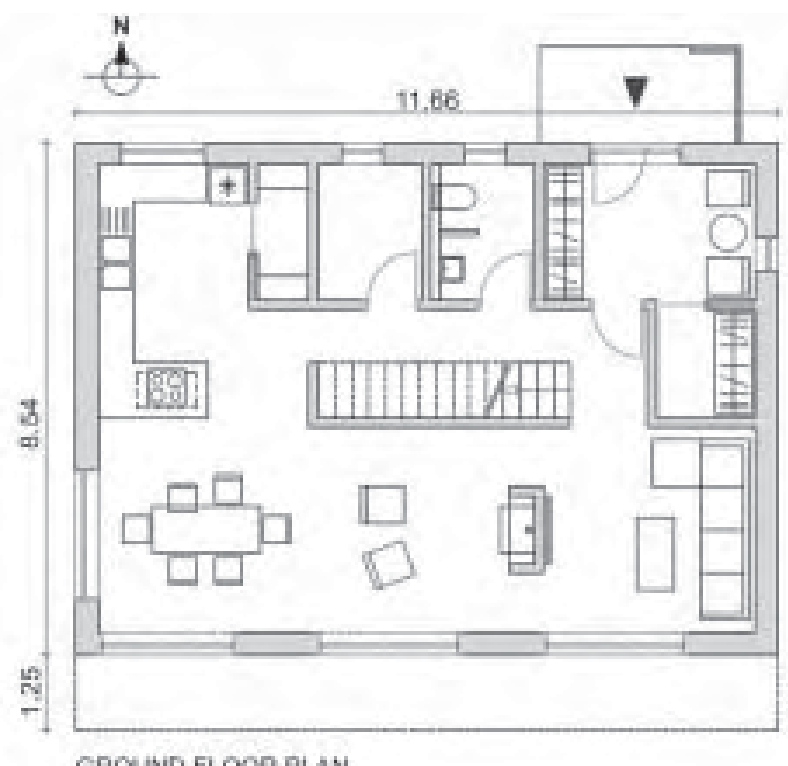

GROUND FLOOR PLAN

Figure 3 Floor plans of the base-case study model

Slika 3. Tlocrt osnovnog modela proučavanja data from http://www.geodetska-uprava.si/DHTML $H M Z / w m$ ppp.htm the considered average annual external temperature is $9.8^{\circ} \mathrm{C}$. The average duration of solar radiation is 1712 hours annually.

\section{Construction}

Exterior walls are constructed in three different variations, as presented in Table 1. For all analysed wall elements, the timber characteristics are of the same class - C22 according to $E N 338$. The $U$-values of other exterior construction elements are in all cases $0.135 \mathrm{~W} / \mathrm{m}^{2} \mathrm{~K}$ for the floor slab, $0.135 \mathrm{~W} / \mathrm{m}^{2} \mathrm{~K}$ for the flat roof and $0.130 \mathrm{~W} / \mathrm{m}^{2} \mathrm{~K}$ for the south-oriented overhang construction above the ground floor area.

\section{Glazing}

Two types of glazing were separately considered in the analysis:

a) a window glazing (Unitop 0.51 - 52 UNIGLAS) with three layers of glass, two low-emissive coatings and Krypton in the cavities for a normal configuration of 4E-12-4-12-E4. The glazing configuration with a $g$-value of $52 \%$ and $U_{\mathrm{g}}=0.51 \mathrm{~W} / \mathrm{m}^{2} \mathrm{~K}$ assures a high level of heat insulation and light transmission, Gustavsen et al. (2007). The window frame $U$-value is $U_{\mathrm{f}}=0.73 \mathrm{~W} / \mathrm{m}^{2} \mathrm{~K}$, while the frame width is $0.114 \mathrm{~m}$.

b) a window glazing with two layers of glass, one lowemissive coating and Argon in the cavity for a normal configuration of 4-16-E4, with a $g$-value of $60 \%$ and $U_{\mathrm{g}}=1.2 \mathrm{~W} / \mathrm{m}^{2} \mathrm{~K}$. The window frame $U$-value is $U_{\mathrm{f}}^{\mathrm{g}}=1.11 \mathrm{~W} / \mathrm{m}^{2} \mathrm{~K}$, while the frame width is $0.116 \mathrm{~m}$.

The glazing-to-wall area ratio (AGAW) of the base case in the south-oriented façade is $27.6 \%$, while the AGAW values of the rest of the cardinal directions are $8.9 \%$ in the north-oriented, $10.5 \%$ in the eastoriented and $8.5 \%$ in the west-oriented façades.

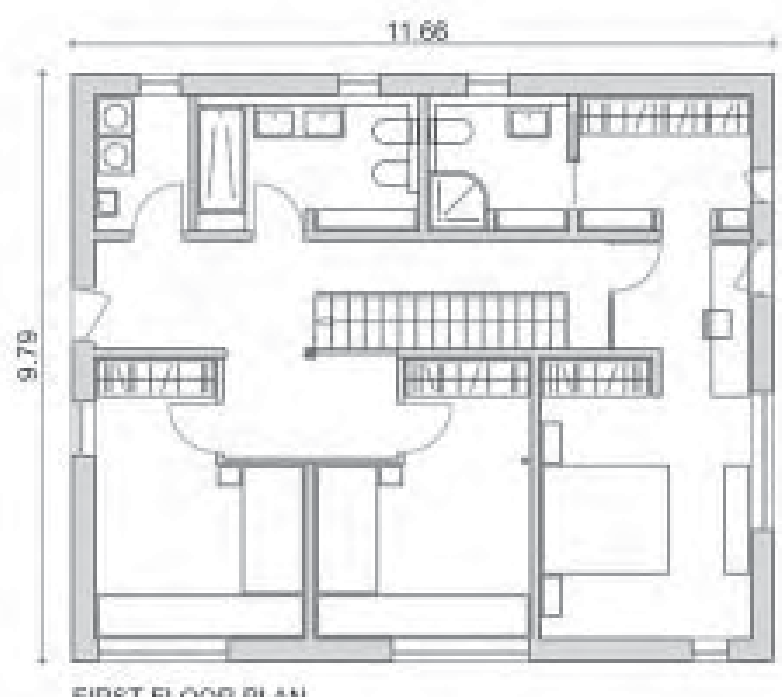

FIRST FLOOR PLAN 

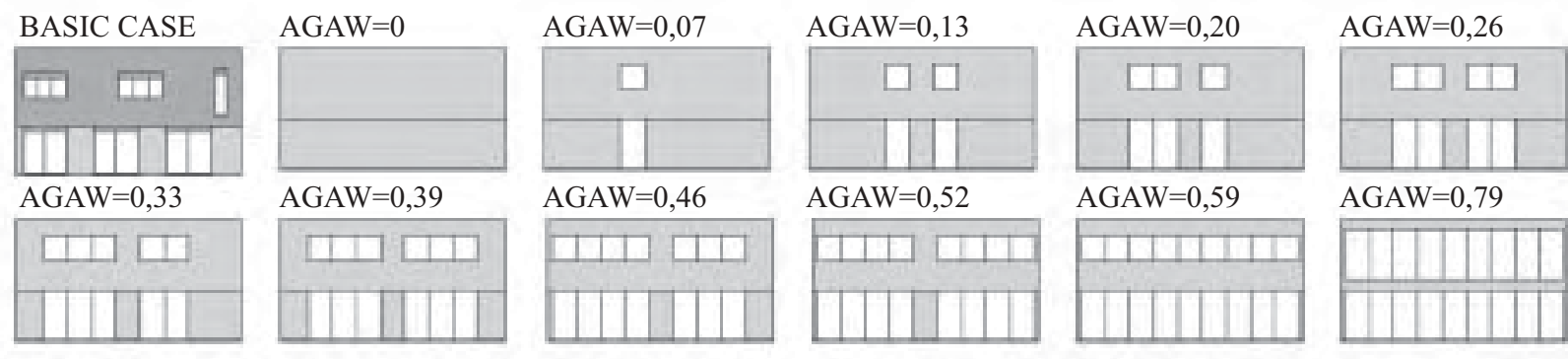

Figure 4 South-oriented façade of the base-case model with schemes of AGAW modification

Slika 4. Južna fasada osnovnog modela sa shemama AGAW modifikacije

\section{Shading}

The house is constructed with a south-oriented extended overhang above the ground floor, which blocks the direct solar radiation from entering the ground floor windows to the south during the summer, while it lets it enter in winter when the angle of incidence of the sun is lower. The rest of the windows on the upper floor and those of the east- and west-oriented walls are shaded with external shading devices.

\section{Internal gains and HVAC}

The house is equipped with a central heat recovery unit. To prevent overheating in the summer period, night ventilation with cooling through manual window was planned. The interior temperatures were designed to a $T_{\min }$ of $20^{\circ} \mathrm{C}$ and $T_{\max }$ of $25^{\circ} \mathrm{C}$. Domestic hot water generation (DHW) and an additional requirement for space heating are covered by a heat pump with a subsoil heat exchanger and, to a minimal extent (5\%), by electric heating.

\section{Variable parameters}

The influence of the glazing area size on energy demand was only studied in the south cardinal direction. It is known from our previous research (Žegarac, 2011; Žegarac and Premrov, 2011) that the influence of the size of incremental glazing area in other cardinal directions $(\mathrm{N}, \mathrm{W}$ and $\mathrm{E})$ on the total energy demand is negative, therefore only the south façade of the building is the point of our interest. Modifications of the glazing area size on the south façade were performed in the range of AGAW from $0 \%$ to nearly $80 \%$. Modi- fications of the glazing area size were made step by step by adding window elements (frame + glazing) to the totally unglazed façade, as presented in Figure 4.

\section{Description of software and calculation method}

The Passive House Planning Package 2007 was used to perform calculations of energy demand. The software, certified as a planning tool for passive houses, providing a surprisingly accurate description of the thermal building characteristics of passive houses, can also be used for low-energy house design. Practice has shown that the results achieved by PHPP software are very similar to the energy demand measured in operating buildings.

\section{RESULTS AND DISCUSSION 4. REZULTATI I RASPRAVA}

\subsection{Results for macro-panel TF 3 system - new} type of passive timber-frame building

4.1. Rezultati za makropanelni TF 3 sustav - nova vrsta pasivne građevine drvene konstrukcije

The results of annual energy demand for heating $\left(Q_{\mathrm{h}}\right)$, cooling $\left(Q_{\mathrm{k}}\right)$ and the sum $\left(Q_{\mathrm{h}}+Q_{\mathrm{k}}\right)$ for the three (TG) and double-layer glazing (DG) as a function of the glazing area size (AGAW $=A_{\mathrm{gl}, \mathrm{S}} / A_{\text {wall, }}$ ) for the south cardinal direction are listed in Table 4 and graphically presented in Figure 5.

The above data clearly show that the increase in the size of the glazing surfaces in the south façade has a relatively positive influence on the heating energy demand and shows almost linear behaviour in both cases

Table 4 Energy demand for TF 3 structural system using triple-layer (TG) and double-layer glazing (DG)

Tablica 4. Energetske potrebe za gradbeni sustav TF 3, uz troslojno (TG) i dvoslojno zastakljenje (DG)

\begin{tabular}{|l|c|c|c|c|c|c|c|}
\hline \multirow{2}{*}{$\begin{array}{l}\text { TF 3 } \\
\text { modification South }\end{array}$} & \multirow{2}{*}{$\boldsymbol{A}_{\text {glass s }} / \boldsymbol{A}_{\text {wall }}$} & \multicolumn{2}{|c|}{$\begin{array}{c}\boldsymbol{Q}_{\mathrm{h}} \\
\mathrm{kWh} / \mathrm{m}^{2} \mathrm{a}\end{array}$} & \multicolumn{2}{|c|}{$\begin{array}{c}\boldsymbol{Q}_{\mathrm{k}} \\
\mathrm{kWh} / \mathrm{m}^{2} \mathrm{a}\end{array}$} & \multicolumn{2}{c|}{$\begin{array}{c}\boldsymbol{Q}_{\mathrm{h}}+\boldsymbol{Q}_{\mathrm{k}} \\
\mathrm{kWh} / \mathrm{m}^{2} \mathrm{a}\end{array}$} \\
\cline { 3 - 8 } & & $\mathrm{TG}$ & $\mathrm{DG}$ & $\mathrm{TG}$ & $\mathrm{DG}$ & $\mathrm{TG}$ & $\mathrm{DG}$ \\
\hline M1S & 0.767 & 11.13 & 23.25 & 11.01 & 12.58 & 22.14 & 35.83 \\
\hline M2S & 0.573 & 13.91 & 24.46 & 6.67 & 8.13 & 20.58 & 32.59 \\
\hline M3S & 0.510 & 14.59 & 24.48 & 5.6 & 6.97 & 20.19 & 31.45 \\
\hline M4S & 0.446 & 15.25 & 24.45 & 4.62 & 5.88 & 19.87 & 30.33 \\
\hline M5S (opt. for TG) & 0.382 & 16.00 & 24.49 & 3.74 & 4.87 & 19.74 & 29.36 \\
\hline M6S & 0.319 & 16.84 & 24.61 & 2.96 & 3.91 & 19.80 & 28.52 \\
\hline M7S & 0.255 & 17.81 & 24.84 & 2.31 & 3.05 & 20.12 & 27.89 \\
\hline M8S & 0.191 & 18.91 & 25.18 & 1.75 & 2.28 & 20.66 & 27.46 \\
\hline M9S & 0.127 & 20.17 & 25.66 & 1.30 & 1.65 & 21.47 & 27.31 \\
\hline M10S (opt.for DG) & 0.064 & 21.48 & 26.16 & 0.93 & 1.14 & 22.41 & 27.30 \\
\hline M11S & 0.000 & 22.99 & 26.84 & 0.64 & 0.76 & 23.63 & 27.60 \\
\hline
\end{tabular}



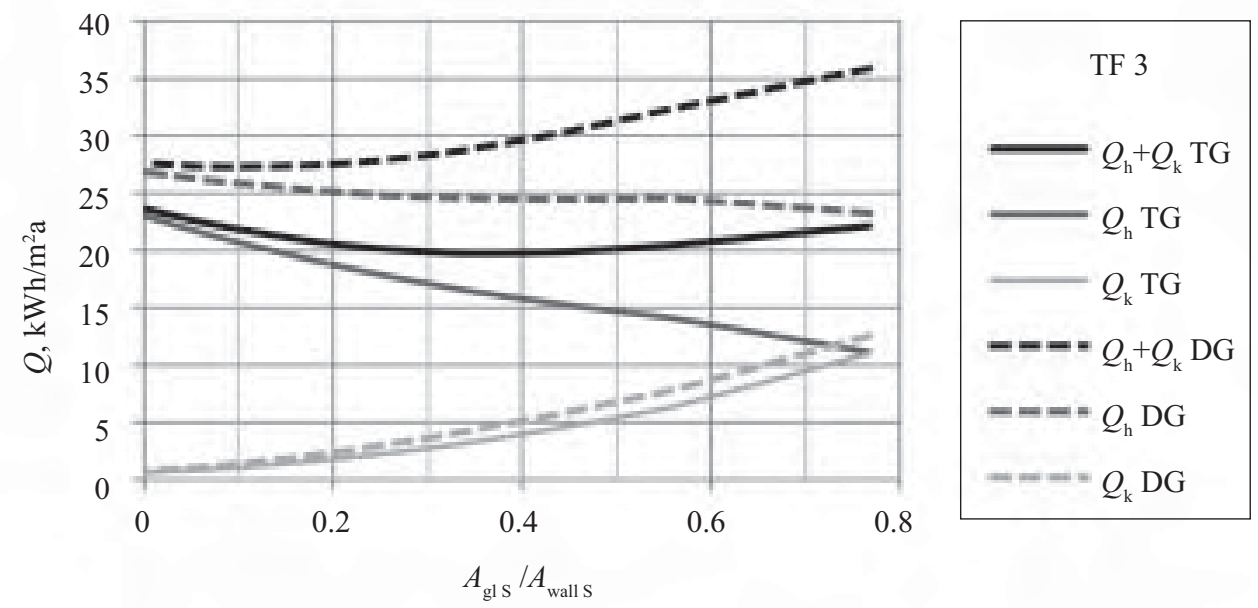

Figure 5 Annual energy demand in the passive TF 3 construction system as a function of AGAW for triple-layer (TG) and double-layer glazing (DG)

Slika 5. Godišnja energetska potreba u pasivnome gradbenom sustavu (TF 3) kao funkcija AGAW za troslojno (TG) i dvoslojno (DG) zastakljenje

of glazing. The function inclination, which physically represents the energy heating benefits, is essentially bigger in the case of the triple-layer glazing. On the other hand, the comparison between patterns of the cooling demand behaviour shows that the glazing type is not so important as heating.

The results for the sum of total energy demand show in both cases an interesting phenomenon related to the optimal point with the lowest $Q_{\mathrm{h}}+Q_{\mathrm{k}}$ demand, which is in the TF 3 construction system by AGAW $=$ 0.382 and results in the energy saving of $3.89 \mathrm{kWh} / \mathrm{m}^{2} \mathrm{a}$ (or $16.46 \%$ ) according to the value by AGAW $=0$ (Table 4). The values for the double-layer glazing are essentially different; the optimum point is at AGAW = 0.064 and produces an energy saving of $0.30 \mathrm{kWh} / \mathrm{m}^{2} \mathrm{a}$ only (or $1.09 \%$ ), see Table 4.

The presented results generally match well with the results of the parametric study research on the effect of the glazing type and size on annual heating and cooling demand made by (Ford et al., 2007). The results carried out for the climate in Milan, which are similar to our case, show that there is practically no significant influence of the glazing type on the cooling demand, while there is a strong impact on the energy heating demand. The results of the Swedish study for the climate in Lund, carried out by Bullow-Hube (2001), also show almost negligible influence of the glazing type on the cooling energy demand.

\subsection{Results for single-panel TFCL 2 system - old type of timber-frame building}

4.2. Rezultati za jednopanelni TFCL 2 sustav - stara vrsta građevina drvene konstrukcije

In our further research, we analyse the influence of glazing in the south facade of the old clasic single-panel frame elements, which were massively installed in the seventies and eighties of the last century and present rather large and important segment of the residential fund, which should certaily undergo adequate energy renovation. Marles' single-panel wall element labeled as TFCL 2, whose geometric and material characteristic are shown in Table 1, with thermal transmittance coefficient $U_{\text {wall }}=$ $0.48 \mathrm{~W} / \mathrm{m}^{2} \mathrm{~K}$, which is much higher than allowed (see Chapter 3) is taken as an example. The results of the numerical analysis with variable glazing share in the south-oriented facade with the use of triple-pane (TG) and double-layer glazing (DG) are numerically presented in Table 5, and graphically in Figure 6.

Generally, when comparing Figure 5 and Figure 6, the results presented for $Q_{\mathrm{h}}, Q_{\mathrm{k}}$ and the sum $Q_{\mathrm{h}}+Q_{\mathrm{k}}$ show that in the case of the TFCL 2 the glazing type is not so

Table 5 Energy demand for classic single-panel TFCL 2 structural system using three (TG) and double-layer glazing (DG).

Tablica 5. Godišnja energetska potreba za TFCL 2, uz troslojno (TG) i dvoslojno zastakljenje (DG)

\begin{tabular}{|l|c|c|c|c|c|c|c|}
\hline \multirow{2}{*}{$\begin{array}{l}\text { TFCL 2 } \\
\text { modification }\end{array}$} & \multirow{2}{*}{\begin{tabular}{c}
$\boldsymbol{A}_{\text {glass s }} \boldsymbol{A}_{\text {wall s }}$ \\
\cline { 3 - 8 }
\end{tabular}} & \multicolumn{2}{|c|}{$\begin{array}{c}\boldsymbol{Q}_{\mathrm{h}} \\
\mathrm{kWh} / \mathrm{m}^{2} \mathrm{a}\end{array}$} & \multicolumn{2}{c|}{$\begin{array}{c}\boldsymbol{Q}_{\mathrm{k}} \\
\mathrm{kWh} / \mathrm{m}^{2} \mathrm{a}\end{array}$} & \multicolumn{2}{c|}{$\begin{array}{c}\boldsymbol{Q}_{\mathrm{h}}+\boldsymbol{Q}_{\mathrm{k}} \\
\mathrm{kWh} / \mathrm{m}^{2} \mathrm{a}\end{array}$} \\
\cline { 3 - 8 } M1S & 0.816 & 35.43 & 49.94 & 10.69 & 11.6 & 46.12 & 61.54 \\
\hline M2S & 0.610 & 42.83 & 55.02 & 7.27 & 8.02 & 50.10 & 63.04 \\
\hline M3S & 0.542 & 44.90 & 56.22 & 6.40 & 7.09 & 51.30 & 63.31 \\
\hline M4S & 0.474 & 46.93 & 57.38 & 5.58 & 6.21 & 52.51 & 63.59 \\
\hline M5S & 0.407 & 49.13 & 58.65 & 4.82 & 5.39 & 53.95 & 64.04 \\
\hline M6S & 0.339 & 51.44 & 60.04 & 4.12 & 4.61 & 55.56 & 64.65 \\
\hline M7S & 0.271 & 53.88 & 61.57 & 3.47 & 3.89 & 57.35 & 65.46 \\
\hline M8S & 0.203 & 56.47 & 63.23 & 2.88 & 3.24 & 59.35 & 66.47 \\
\hline M9S & 0.136 & 59.22 & 65.05 & 2.35 & 2.64 & 61.57 & 67.69 \\
\hline M10S & 0.068 & 61.98 & 66.89 & 1.88 & 2.11 & 63.86 & 69.00 \\
\hline M11S & 0.000 & 64.93 & 68.93 & 1.47 & 1.64 & 66.40 & 70.57 \\
\hline
\end{tabular}



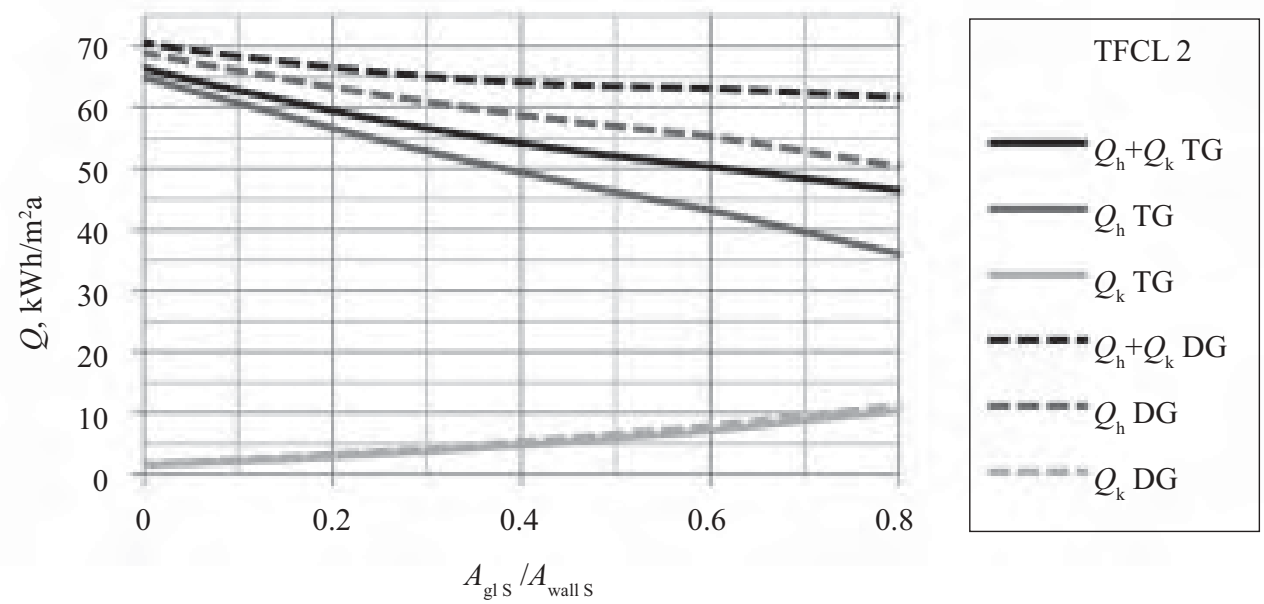

Figure 6 Annual energy demand for classic single-panel TFCL 2 construction system as a function of AGAW for triple-layer (TG) and double-layer glazing (DG).

Slika 6. Godišnja energetska potreba u klasičnome jednopanelnom gradbenom sustavu TFCL 2 kao funkcija AGAW za troslojno (TG) i dvoslojno (DG) zastakljenje

decisive as in the case of TF 3 system. There is practically no influence on the cooling demand at all. In comparison to the TF 3 , the functional optimum (lowest $Q_{\mathrm{h}}+Q_{\mathrm{k}}$ value) disappears and the $Q_{\mathrm{h}}+Q_{\mathrm{k}}$ function shows almost linear dependence on AGAW value. The inclination of the function line depends on the glazing type ( $U_{\mathrm{g}}$-value) and it is bigger in the case of the triple-layer glazing (TG). Consequently, in this case, as calculated from Table 5, energy decrease caused by an increase in the total glazing area (measured from AGAW $=0$ to AGAW $\approx$ 0.80 ) represents $20.28 \mathrm{kWh} / \mathrm{m}^{2} \mathrm{a}$ or $30.54 \%$. For the double-layer glazing (DG), these values are $9.03 \mathrm{kWh} /$ $\mathrm{m}^{2} \mathrm{a}$ or $12.80 \%$. According to these results, it can be concluded that larger glazing area in the south façade significantly increase energy savings (measured in percents), which are higher for the TFCL 2 system than for the new macro-panel TF 3 system.

\subsection{Results for single-panel TFCL 3 system - case} of renovation

4.3. Rezultati za jednopanelni TFCL 3 sustav - primjer obnove

As presented in Table 1, the system has been fictively developed from the TFCL 2 old system by inser- ting an additional layer of insulation in the external side of timber frame. The $U_{\text {wall }}$-value, therefore, decreased from $0.48 \mathrm{~W} / \mathrm{m}^{2} \mathrm{~K}$ to $0.30 \mathrm{~W} / \mathrm{m}^{2} \mathrm{~K}$. The results of annual energy demand for heating $\left(Q_{\mathrm{h}}\right)$, cooling $\left(Q_{\mathrm{k}}\right)$ and the sum $\left(Q_{\mathrm{h}}+Q_{\mathrm{k}}\right)$ for the three (TG) and double-layer glazing (DG) as a function of the glazing area size (AGAW $\left.=\mathrm{A}_{\mathrm{gl} . \mathrm{S}} / \mathrm{A}_{\text {wall,S }}\right)$ for the south cardinal direction are listed in Table 6 and graphically presented in Figure 7.

The presented results clearly show, just like the TFCL 2, that the glazing type has practically no influence on energy demand for cooling, but the heating function is still essentially bigger in the case of the triple-layer glazing. For the sum of $Q_{\mathrm{h}}+Q_{\mathrm{k}}$ it can be observed that in the case of the double-layer glazing (DG) the optimal point of AGAW appears with AGAW = 0.336 (Table 6). It is interesting that the function dependence on the AGAW is almost constant and the values only vary in the range from $47.36 \mathrm{kWh} / \mathrm{m}^{2} \mathrm{a}$ at $\mathrm{AGAW}=\mathrm{AGAW}_{\mathrm{opt}}=0.336$ to $50.07 \mathrm{kWh} / \mathrm{m}^{2} \mathrm{a}$ at AGAW $=0$. In this case, the total energy demand is practically independent on the size of glazing, which is, of course, very convenient from the economical point of view.

Table 6 Energy demand for fictively improved single-panel TFCL 3 structural system using three (TG) and double-layer glazing (DG).

Tablica 6. Energetska potreba za TFCL 2, uz troslojno (TG) i dvoslojno zastakljenje (DG)

\begin{tabular}{|l|c|c|c|c|c|c|c|}
\hline \multirow{2}{*}{$\begin{array}{l}\text { TFCL 3 } \\
\text { modification South }\end{array}$} & \multirow{2}{*}{$\boldsymbol{A}_{\text {glass }} / \boldsymbol{A}_{\text {wall s }}$} & \multicolumn{2}{|c|}{$\begin{array}{c}\boldsymbol{Q}_{\mathrm{h}} \\
\mathrm{kWh} / \mathrm{m}^{2} \mathrm{a}\end{array}$} & \multicolumn{2}{|c|}{$\begin{array}{c}\boldsymbol{Q}_{\mathrm{k}} \\
\mathrm{kWh} / \mathrm{m}^{2} \mathrm{a}\end{array}$} & \multicolumn{2}{c|}{$\begin{array}{c}\boldsymbol{Q}_{\mathrm{h}}+\boldsymbol{Q}_{\mathrm{k}} \\
\mathrm{kWh} / \mathrm{m}^{2} \mathrm{a}\end{array}$} \\
\cline { 3 - 8 } & & $\mathrm{TG}$ & $\mathrm{DG}$ & $\mathrm{TG}$ & $\mathrm{DG}$ & $\mathrm{TG}$ & $\mathrm{DG}$ \\
\hline M1S & 0.810 & 23.16 & 36.87 & 10.80 & 11.26 & 33.96 & 48.13 \\
\hline M2S & 0.606 & 28.45 & 40.14 & 7.14 & 8.14 & 35.59 & 48.28 \\
\hline M3S & 0.538 & 29.89 & 40.79 & 6.17 & 7.17 & 36.06 & 47.96 \\
\hline M4S & 0.471 & 31.32 & 41.40 & 5.28 & 6.22 & 36.60 & 47.62 \\
\hline M5S & 0.404 & 32.86 & 42.10 & 4.44 & 5.30 & 37.30 & 47.40 \\
\hline M6S (opt.for DG) & 0.336 & 34.53 & 42.92 & 3.69 & 4.44 & 38.22 & 47.36 \\
\hline M7S & 0.269 & 36.35 & 43.87 & 3.00 & 3.64 & 39.35 & 47.51 \\
\hline M8S & 0.202 & 38.31 & 44.95 & 2.40 & 2.92 & 40.71 & 47.87 \\
\hline M9S & 0.135 & 40.43 & 46.17 & 1.87 & 2.26 & 42.30 & 48.43 \\
\hline M10S & 0.067 & 42.57 & 47.42 & 1.42 & 1.69 & 43.99 & 49.11 \\
\hline M11S & 0.000 & 44.89 & 48.85 & 1.05 & 1.22 & 45.94 & 50.07 \\
\hline
\end{tabular}



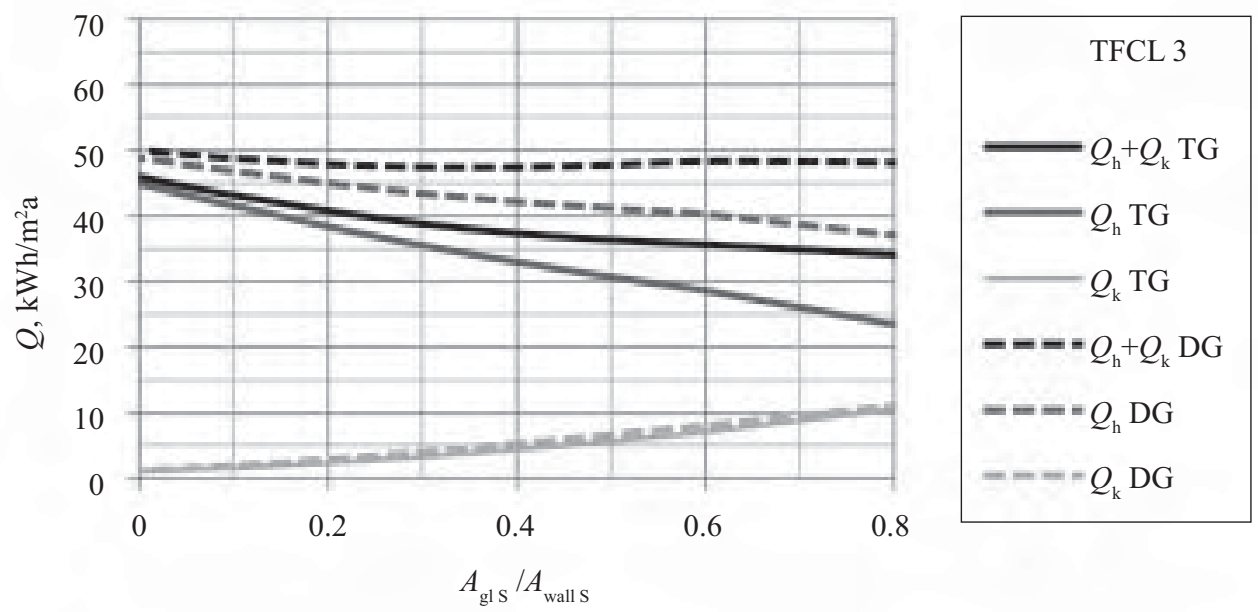

Figure 7 Annual energy demand for the classic single-panel TFCL 3 construction system as a function of AGAW for triple-layer (TG) and double-layer glazing (DG)

Slika 7. Godišnja energetska potreba u klasičnome jednopanelnom gradbenom sustavu TFCL 3 kao funkcija AGAW za troslojno (TG) i dvoslojno (DG) zastakljenje

On the other hand, by using the triple-layer glazing (TG), AGAW does not reach the optimum point, and the enlarged size of glazing still positively effects the total energy demand. Consequently, in this case, as calculated from Table 6, energy decrease caused by an increase in the total glazing area (measured from AGAW $=0$ to $\mathrm{AGAW} \approx 0.80$ ) represents $11.98 \mathrm{kWh} /$ $\mathrm{m}^{2} \mathrm{a}$ or $26.08 \%$. The percentage of energy saving is thus not essentially lower as by TFCL 2 (30.54\%). When comparing the values for TFCL 2 (Table 5) and the values for the renewed TFCL 3 system (Table 6), it is important to point out that by inserting an additional insulation the total energy demand was decreased on an average of about $20 \mathrm{kWh} / \mathrm{m}^{2} \mathrm{a}$.

Therefore, if approaching a renovation process only from the point of energy saving and not from an economic viewpoint, the use of the triple-layer glazing is definitely a much better solution. For this reason, findings by Žegarac (2011) should be considered, where the generalisation of the treated energy problem was developed on only one single independent variable
( $U_{\text {wall }}$-value). The analysis was performed on the same case study model as in this numerical analyse, using triple-layer glazing only. The possibility of analysing the relationship between the optimal glazing size in south-oriented external wall elements $\left(\mathrm{AGAW}_{\text {opt }}\right.$ ) related to $Q_{\mathrm{h}}+Q_{\mathrm{k}}$ energy demand and thermal transmittance of the wall element ( $U_{\text {wall }}$-value) was demonstrated. The data presented in Figure 8 show the values of AGAW, at which the total sum of heating and cooling demand reaches the lowest value, dependant on the $U$ value of the selected external wall element, independently of the type of construction system.

Figure 8 shows that the optimum or the convergence of the function curves for $\mathrm{AGAW}_{\text {opt }}$ appears only in systems with the $U_{\text {wall }}$-value $\leq 0.193 \mathrm{~W} / \mathrm{m}^{2} \mathrm{~K}$. A higher $U_{\text {wall }}$-value corresponds to a higher optimal share of the south oriented glazing size. By reaching the limiting $U_{\text {wall }}$-value $=0.193 \mathrm{~W} / \mathrm{m}^{2} \mathrm{~K}$, the values for an optimal AGAW converge towards the maximal glazing surface. For the construction systems with the $U_{\text {vall }}$-value $>0.193 \mathrm{~W} / \mathrm{m}^{2} \mathrm{~K}$ no optimum or convergence for

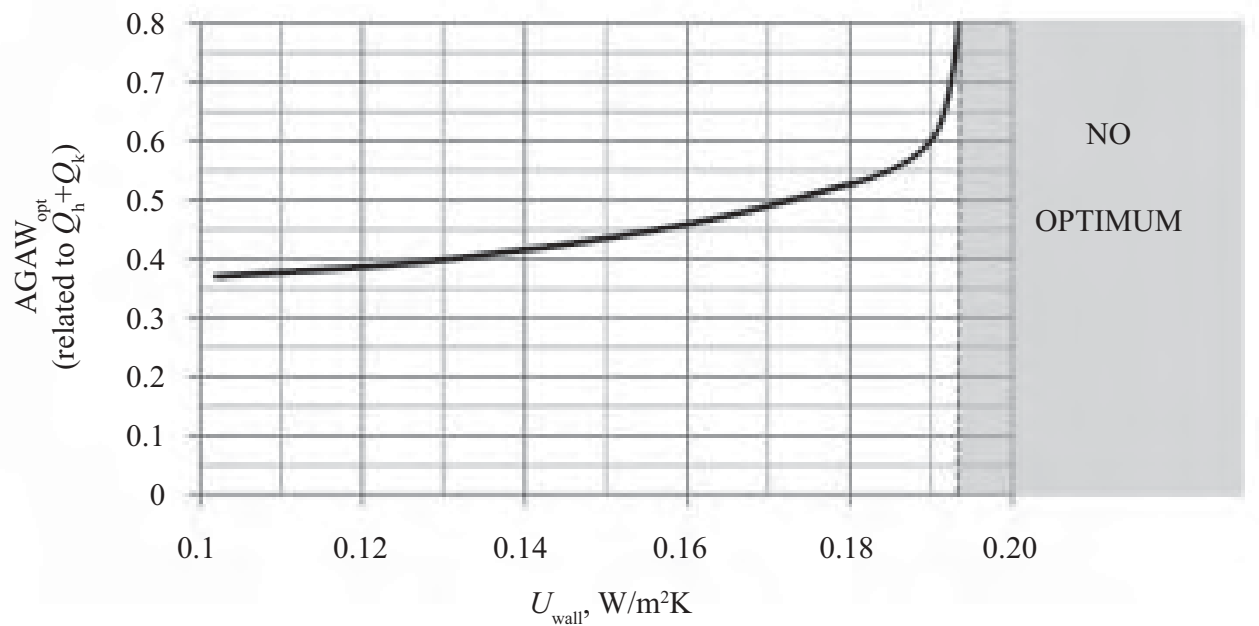

Figure 8 Optimal values of AGAW in the south oriented external wall element as a function of the $U_{\text {wall }}$-value for timber construction systems using triple-layer glazing

Slika 8. Optimalne vrijednosti AGAW u južno orijentiranim vanjskim zidnim elementima kao funkcija $U_{\text {wall }}$-vrijednosti za drvene konstrukcijske sustave koji se koriste troslojnim zastakljenjem 
AGAW appear, the lowest $Q_{\mathrm{h}}+Q_{\mathrm{k}}$ is reached at the maximum AGAW value. The whole procedure is widely described by Žegarac Leskovar (2011).

This principle is going to be applicable from a practical point of view in the cases of renovation of old timber houses, where firstly the average $U_{\text {wall }}$-value is reduced with the installation of an additional layer of insulation, and consequently the optimal AGAW value is determined according to the new reduced $U_{\text {wall }}$-value. Finally, the proper size of glazing surfaces can be installed into south-oriented exterior, which contributes to better energy performance of the building.

\section{CONCLUSION}

\section{ZAKLJUČAK}

This numerical parametric study shows evidently that in the modern passive prefabricated timber construction (wall system TF 3) double glazing hardly ever pays off regarding energy savings, while triple-layer glazing significantly increases energy savings. Therefore, in order to achieve heating and cooling energy savings in the prefabricated timber-frame structures, built up according to the contemporary passive standards, by installing larger glazing surfaces in the south façade, it is only reasonable to use the glazing of the highest quality, i.e. triple-layer glazing. In the case of the conventional single-panel timber-frame prefabricated timber construction (wall system TFCL 2), which had been used in the seventies and eighties of the last century, nowadays more or less in need of renovation regarding energy efficiency, the type of glazing is much less influential than in the contemporary buildings. Numerical results evidently show that energy savings in the case of triple-layer glazing are higher than in the case of double-layer glazing. However, these differences are much smaller than in the contemporary passive system. In this case, renovation may be a combination of additional insulation and optimal share of south façade glazing. The decision on the choice of the glazing quality is up to the investor, or up to the cost-benefit calculation, i.e. the ratio between the renovation investment and energy savings during future exploitation. As shown in Figure 8, in the case of the triple-layer glazing, from the cost-benefit point of view, it is of prime importance to adequately decrease energy transmittance of the exterior and consequently decrease the share of the glazing surface in the south façade.

\section{REFERENCES}

\section{LITERATURA}

1. Bülow-Hübe, H., 2001: The effect of glazing type and size on annual heating and cooling demand for Swedish offices. Report No TABK--01/1022. Department of Construction and Architecture, Lund University, Division of Energy and Building Design, Lund.

2. European Committee for Standardization 2003: EN 338:2003 E: Structural timber - Strength classes. Brussels.

3. Feist, W., 2007: PHPP 2007 Guide book. Passivhaus Institut Dr. Volfgang Feist Darmstadt.
4. Ford, B.; Schiano-Phan, R.; Zhongcheng, D., 2007: The passivhaus standard in European warm climates, Design guidelines for comfortable low energy homes - Part 2 and 3. Passive-On Project report. School of the Built Environment, University of Nottingham.

5. Gustavsen, A. et al. 2007: State-of-the-Art Highly Insulating Window Frames. Research and Market Review, Oslo http://dx.doi.org/10.2172/941673.

6. Johnson, R. et al. 1984: Glazing energy performance and design optimization with daylighting. Energy and Buildings 6: 305-317. http://dx.doi.org/10.1016/0378-7788(84)90014-8.

7. Kitek Kuzman, M.; Medved, S.; Vratuša, S., 2010: Evaluation of Slovenian contemporary timber construction. Drewno 53(183): 85-100.

8. Natterer, J., 2009: Massivholz-konstruktionen: Herausforderung für eine nachhaltige Ökobilanz. In: Kitek Kuzman (Ed.): Building with Timber, Challenge and Opportunity for Slovenia. University of Ljubljana, Biotechnical Faculty, Ljubljana, pp. 18-21.

9. Praznik, M.; Kovič, S., 2010: With active systems and thermal protection to passive and plus energy residential buildings. In: Premrov M. (Ed); Žegarac Leskovar, V. (Ed): International conference proceedings on energy efficiency in architecture and civil engineering, University of Maribor, Faculty of civil engineering, Maribor, pp 45-57.

10. Premrov, M., 2008: Timber frame houses. In: Handbook 1, TEMTIS project, (Educational materials of designing and testing of timber structures), Ostrava: VŠB-tu, Fakulteta stavební, $15 \mathrm{p}$.

11. PURES, 2010: Pravilnik o učinkoviti rabi energije v stavbah, Ur.1. RS št. 52/2010

12. Rules on the methodology of construction and issuance of building energy certificates, Official Gazette RS, $77 / 2009$.

13. Rules on efficient use of energy in buildings, 2010: Official Gazette RS, 52/2010.

14. SORS Statistical office of the Republic Slovenia, 2011: Statistical Yearbook.

15. Steadman, P.; Brown, F., 1987: Estimating the exposed surface area of the domestic stock. Energy and urban built form. Centre for Architectural and Urban Studies, University of Cambridge, pp. 113-131.

16. Vratuša, S.; Kitek Kuzman, M.; Kilar, V., 2011: Structural particulars of glued laminated beams of variable height. Drewno 54 (185):19-38.

17. Žegarac Leskovar, V., 2011: Development of Design Approach for the Optimal Model of an Energy-Efficient Timber House. PhD Thesis, Graz University of Technology.

18. Žegarac Leskovar, V.; Premrov, M., 2011: Impact of the proportion of glazing surface in south facade on energy efficiency of prefabricated timber buildings. Les Wood 63 (3): 55-64. www.geodetska-uprava.si/DHTML_HMZ/ wm_ppp.htm (Accessed 15 July 2011).

\section{Corresponding address:}

Assist. Prof. MANJA KITEK KUZMAN, Ph.D.

University of Ljubljana, Biotechnical Faculty

Department of Wood Science and Technology

Rožna dolina, C.VIII/34

1000 Ljubljana, SLOVENIA

e-mail: manja.kuzman@bf.uni-lj.si 